\title{
Electric vehicles in |Brazil as an alternative to the reduction of air pollution caused by fossil fuels
}

\author{
Nilcéia Cristina dos Santos ${ }^{1}$, Reinaldo Gomes da Silva ${ }^{2}$, Alberto Martins Junior ${ }^{2}$ \\ ${ }^{1}$ Faculty of Technology of Piracicaba "Dept. Roque Trevisan" (FATEC PIRACICABA) CEETPS, Paula Souza \\ Technological Education State Center 1120 Deacon Jair de Oliveira, S/N, Piracicaba/SP (Brazil) Phone number: +55 19 \\ 99614-1327 or +55 19 3411-2454 E-mail: nilceia_santoss@yahoo.com.br, ncsantoss@ hotmail.com \\ ${ }^{2}$ Engineering School of Piracicaba (EEP) FUMEP, Municipal Foundation of Teaching of Piracicaba 1120 Monsignor \\ Martin Salgot, 560, Piracicaba/SP (Brazil) Phone number: +55 19 99602-1218 Email: reinaldorgda @ gmail.com, \\ amartins@fumep.edu.br
}

\begin{abstract}
The pollution has increased of significant form since $1^{\circ}$ Industrial Revolution. The atmospheric pollution is most significant for provoking illnesses and deaths in the whole world and the main cause is the derivative of the fosseis fuel burning. In Brazil the happened pollution of the transport represents the main generating source of pollution. Although $88 \%$ of the fleet of cars produced in Brazil have engines flex that they emit little pollutant gases, exists $36 \%$ of the composed national fleet for models with superior age of 20 years, that use gasoline and diesel and are responsible for emitting about 150 times more pollutant than the new models. In 2016, had died in the world about 6,5 million people due the pollution of air and in Brazil, had been approximately 22 a thousand people and the perspective is that 36 thousand deaths occur up to 2040. Brazil has assigned international agrements to reduce the emission of $\mathrm{CO}^{2}$ and, internaly, creat the Program of Control of Air Pollution by automotive vehicles. Although these initiatives, little is had advanced in the reduction accomplishes of the emission. It is necessary to rethink the question of the use of the electric vehicles as alternative to assist in the reduction of the emissions of pollutant gases.
\end{abstract}

\section{Keywords: electric car, fossil fuels, pollution of air, $\mathrm{Co}^{2}$ health, emission.}

\section{Introduction}

Since the sprouting of the engine the internal combustion, in ends of century XIX until the current moment, its use as half of transport has contributed of decisive form for the increase of the pollution and the consequent aggravation of the effect greenhouse. This occurs due to the fósseis fuel use that has been pointed with one of the main accelerators of these gases.

In accordance with the Ministry of Science, Technology and Innovation (MCTI), 1.246.477 Brazil emitted $\mathrm{Gg}$ of $\mathrm{Co}^{2}$ in 2010, being that approximately $32 \%$ of these emissions had been attributed to the energy sector, of which the transport sector represented $41.9 \%$ and the road transport, $38.5 \%$ (BRAZIL, 2013).

In Brazil, in the sector of transports it has the predominance of the use of the engine the combustion as propulsion form to propagate, demonstrating to be the sector that more emits, and also is what more it presents greater possibility of reduction of emissions, for example, the substitution of the trucks for trains.
According to Martins (2015) the permanence of the vehicle with engine as combustion if must to the fact of it have been bred in an environment favorable its which had permanence, to a series of economic factors and technician who provides advantages and becomes it more income-producing in relation the electric car.

However, the fact of the oil deposits to be if depleting and due to the world-wide effort for the reduction of the fossils fuel burning (oil, coal and natural gas) and its consequences for the increase of the global heating and the ambient degradation, comes becoming it impracticable as raw material in the next decades.

Goldenstein and Azevedo (2006) affirm that the automotives vehicles are the main factors of risks for the health human being and to the environment, therefore the vehicles moved to the gasoline and diesel pollute air with carbon monoxide (CO), nitrogen oxides (NOX) and hydro-carbons (HC).

In such a way, with the question of the sustainability in evidence, to invest in vehicles that do not pollute or pollute less is essential.

So for the sustainability happens is necessary to rethink urban mobility, with the use of vehicles that have none or little emission of gases. Between these possible vehicles they are the electric cars, the vehicles the hydrogen cell and the vehicles of hydrogen combustion that do not emit $\mathrm{Co}^{2}$.

However, in Brazil the use of electric vehicles is insignificant if compared with the total of sold vehicles. According to Anfavea (2017) are sold annually about 3 million vehicles (light commercial cars and), being that of this total the amount of vehicles with hybrid and electric engine (internal or external source) is small.

In 2016, the Brazilian automotive production for type of fuel was distributed in the following way: $4 \%$ with engines by gasoline, $88 \%$ with engines flex (etanol/gasoline), $8 \%$ with engines diesel. Although if it does not produce electric vehicles in Brazil of total sales only $0.1 \%$ possess engines hybrid and electric (internal or external source), that is, only 1091 units (ANFAVEA, 2017).

These data demonstrate how much Brazil is unbalanced in relation to other countries with respect to the sell of electric cars. According to Barbosa (2016) the countries that more are used of green models are in first the Norway with $22,9 \%$ of the fleet, Holland with $5,2 \%$, the United kingdom with 1,2\%, Frank and the United States with $0,8 \%$ and Germany with $0,6 \%$. 
Ahead of displayed this article it has for objective to present an analysis concerning electric and hybrid vehicles, as alternative to the fossil fuel aiming at to reduce the emission of effect gases harmful greenhouse and gases to the health human being.

It is important that the society understands that the current systems of transport have negative impacts in the health human being and the environment.

The important to evidence that despite the complete substitution of the conventional vehicles for the electric ones was possible, would not decide all the problems associates to the transport, such as the congestions in the urban centers or the necessity of new infrastructures for urban mobility.

\section{LITERATURE REVIEW}

This revision of literature has as objective to display some concepts and information that will facilitate the understanding of the Brazilian automotive market and the question of the ambient and economic impact in Brazil.

\subsection{Electric vehicles}

The technology of the electric car started to be developed in century XIX competing with the moved vehicles the vapor and the internal combustion. The electric vehicles are those that possess electric drive for propulsion being able to include electric trains, airplanes, boats, motorcycles, trucks and cars.

According Erber (2010), the called electric vehicles present three families of technology of electric cars with the following conformations:

a) The Electric vehicles (EVs), has your propulsion through electric engines, which stores energy in batteries obtained by external sources, such as Electric power supply network.

b) the hybrid vehicles (HEVs), if do not connect to a external power plant, them the internal combustion that sets in motion the generator, being able to be the gasoline, etanol or the oil combines electric engines with engines diesel and loads the batteries.

c) the hybrid vehicles of the type plug-in (PHEVs) its batteries can in such a way be recharged by engines the combustion how much for a on external source to the electric net for the recharge of its batteries.

The adoption of the electric vehicles involves diverse aspects: economic, technological, cultural, energy, among others (IPEA, 2015).

However the substitution of the current moved vehicles of fossils fuels will not happen by fast and simple form, since the model of transport and its energy matrices are consolidated more than a century.

Therefore, the diffusion of the electric car requires politics effective that redirect on the question of urban mobility and changes in the routes of the automotive sector.

Tiger (2006) analyzed the process of diffusion of the electric car on three factors: institucional, economic and technician.

The institucional factors are called institucional arrangements, formed for formal restrictions (rules, laws and constitutions) and informal (behavior, behavior), that together they define the structure of incentives the society, especially in the economic system, mentioning the form for which a economic activity can cooperate and compete (FIANI, 2011; NORTH and DAVIS, 1971).

Some politics would assist in the diffusion of electric cars, such as: subsidies and tax incentives, infrastructure of supplying, stimulaton to the innovation, partnerships between the State and the private sector, ambient regulation for the automotivo sector e, development of a clean energy matrix.

The economic factors are 0 variable that will be able to affect the planning and the capacity of a sector to profit during definitive period, such as: price of the raw material, cost of the workmanship hand, scale of production, level of specialization, possibility of vertical integration, capacity to catch the trends of the market, logistic structure of distribution channels, capital for marketing and the production and the development. These are important factors for the competitiveness of the companies.

The factors technician consider the evolution of the batteries for electric cars, a condicionante factor for the diffusion of this type of vehicle, therefore to be used battery must aim at bigger autonomy, minor weight and low cost, since it is responsible for supplying the energy that sets in motion the electric engines and the wheels (MARTINS, 2015).

Different types of batteries exist, but the lithium ion batteries are considered most promising for the next decades with possible production and development, having searched in such a way to improve its performance as to reduce its costs (GERSSEN-GONDELACH, FAAIJ, 2012).

One notices that the institucional and economic factors, added to the factors technician, can favor the diffusion of the electric car.

In Brazil plants of electric cars do not exist, have in circulation some imported models: Toyota Prius, Lexus CT200h, Ford Fusion Hybrid, Mitsubishi Outlander PHEV, BMW i3 and i8.

Also it does not have in the country incentives for the diffusion of the electric vehicle, such as the tax exemption, available infrastructure in national scale with net of ranks for recharge of batteries, among other aspects that the price of the vehicle reduced to make possible its commercialization and production in industrial scale.

Another factor that hinders the diffusion it electric car is the energy crisis for which Brazil comes in recent years passing, due to rain lack that affects the situation of the reservoirs of the hydroelectrics, fact that makes the government to set in motion thermal the a natural gas with consequence in the increase of the tariffs (PAMPLONA, 2017).

In relation to the ambient questions, the precarious maintenance and the increase of the Brazilian fleet of automotive vehicles about the internal combustion, had made Brazil to search to reduce the levels of emission of the main pollutants to propagate.

According to Ministry of the Environment (2017) was created in 06 of May of 1986 the Resolution number 18 of the National Advice of the Environment (CONAMA) that it created the Program of Control of Pollution of Air for automotive vehicles (PROCONVE), co-ordinated for the 
Brazilian Institute of the Environment and Renewable Natural Resources (IBAMA), that the 2013 defined the first limits of emission for light vehicles for the period of 1988, and contributed for the attendance to the Standards of Quality of Air instituted by the National Program of Quality control of Ar (PRONAR).

Although to follow such programs of pollution reduction, Brazil does not follow the global efforts to reduce the fossils fuel burning (oil, coal and natural gas).

\subsection{Impacts of the $\mathrm{Co}^{2}$ Emission in Brazil}

Brazil is enters the main countries that more emit $\mathrm{Co}^{2}$ (carbonic gas) in the atmosphere, in the period among the years of 2000 the 2011, had an increase of $34 \%$ in the amount of set free gases, these numbers shows that in the turn of century 20 for the 21 , the Brazilian emission was of $327.983,81 \mathrm{kt}$ e, up to 2011 , this amount had increased for 439.412, $94 \mathrm{kt}$. (MARTINS, 2017).

The Brazilian energy matrix is based on sources renewed, as, etanol, and in sources you did not renew as oil and natural gas, that contribute so that the country is the tenth consuming greater of energy of the world and the third greater of the continent, being behind only of the United States and Canada (MARTINS, 2017).

In accordance with Barbosa (2016) in ranking worldwide of the countries with air more polluted, that is, with pollutant particle concentration in the atmosphere that exceeds up to 14 times the level considered safe for the World-wide Organization of Saúde (OMS), is (Table 1):

Table 1 - The ten countries with air more polluted
\begin{tabular}{|c|l|c|}
\hline ORDER & \multicolumn{1}{|c|}{ COUNTRY } & $\begin{array}{c}\text { PARTICLE } \\
\text { CONCENTRATION }\end{array}$ \\
\hline 1 & Mongólia & $279 \mathrm{ug} / \mathrm{m} 3$ \\
\hline 2 & Botsuana & $216 \mathrm{ug} / \mathrm{m} 3$ \\
\hline 3 & Paquistão & $198 \mathrm{ug} / \mathrm{m} 3$ \\
\hline 4 & Senegal & $145 \mathrm{ug} / \mathrm{m} 3$ \\
\hline 5 & Arábia Saudita & $143 \mathrm{ug} / \mathrm{m} 3$ \\
\hline 6 & Egito & $138 \mathrm{ug} / \mathrm{m} 3$ \\
\hline 7 & Emirados Árabes & $132 \mathrm{ug} / \mathrm{m} 3$ \\
\hline 8 & Irã & $124 \mathrm{ug} / \mathrm{m} 3$ \\
\hline 9 & Nigéria & $124 \mathrm{ug} / \mathrm{m} 3$ \\
\hline 10 & Kuwait & $123 \mathrm{ug} / \mathrm{m} 3$ \\
\hline $\mathbf{4 8}$ & BRASIL & $\mathbf{4 8 ~ u g} / \mathbf{m 3}$ \\
\hline
\end{tabular}

Fonte: (WHO, 2014).

In the ranking of the most polluted countries, Brazil was $48^{\circ}$, with an average of $48 \mu \mathrm{g} / \mathrm{m}^{3}$ of particulate material suspended in the air.

WHO has identified that air pollution causes more than 3.6 million premature deaths per year (WHO, 2014).

In order not to pose a health risk, the annual concentration of these particles in the atmosphere should be no more than 20 micrograms per cubic meter (20 ug / $\mathrm{m} 3$ ), so Brazil is twice as permissible.

The main causes of poor air quality in the world are inefficient modes of transportation, fuel combustion and tailings, power plants and industrial activities, and natural phenomena such as sandstorms and burning of forests and forests.

The most significant agents of irritation of the respiratory system are the so-called PM10, inhalable particles composed of substances such as sulfur dioxide, carbon monoxide, oxides of nitrogen, hydrocarbons, ozone and lead.
The data on pollution and its harmful effects on human health pointed out by WHO has been a source of concern for world leaders who have come together to set plans to reduce deaths linked to this threat by 2030

\subsection{International Agreements for the Reduction of Emission of Pollutant Gases}

The Conference of the Parties (COP) is the supreme body of the United Nations Framework Convention on Climate Change (UNFCCC), which annually convenes countries at world conferences, and its decisions are collective and consensual, which can only be taken if they are accepted unanimously by the participating countries, being sovereign and valid for all.

The UNFCCC was adopted at the 192-nation United Nations Conference on Environment and Development (Rio-92), which aimed to create rules to limit global warming through a variety of policies, including greenhouse gas emissions targets the first meeting of the Conference of the Parties (COP-1) took place in 1995, in Berlin in Germany (IPEA, 2015).

According to IPEA (2015), in 1997, the Kyoto Protocol was signed by 37 countries in 1997, which sought to reduce the emissions of the signatory countries by $5.2 \%$ in relation to 1990 , even though there were differentiated targets for each country.

In 2009, the Copenhagen Accord (COP-15) was signed, which set national emissions targets, which were intended to be sufficient to limit global warming to a maximum temperature rise of $2^{\circ} \mathrm{C}$. (IPEA, 2015).

According to Avansini (2017), in 2015, under the Paris Agreement (COP-21), for the containment of global warming, signed by Brazil, greenhouse gas emissions should be reduced by $37 \%$ by 2025 and limit the average global temperature increase.

In 2016, Brazil participated in the Climate Conference (COP-22) held in Marrakesh, Morocco, with a commitment to meet an ambitious goal: to reduce greenhouse gas emissions by $43 \%$ by 2030 , compared to 2005 (AVANSINI, 2017).

At the Climate Conference (COP 23), held in 2017 in Bonn, Germany, Brazil presented the country's environmental policy, which involves the dissemination of federal efforts to preserve the Amazon rainforest, according to the Brazilian government. 28\% decline in deforestation in the region this year compared to last year (BRAZIL, 2017).

Other Brazilian targets that increase the share of sustainable bioenergy in the energy matrix to approximately $18 \%$, restore and reforest 12 million hectares of forests, and increase the share of renewable energy in the composition of the energy matrix by $45 \%$ by 2030.

According to Oliveira (2017), among the emission reduction targets, the new Brazilian plan proposes a cut of $66.5 \mathrm{~g} / \mathrm{km}$ in $\mathrm{CO}^{2}$ emissions by 2030 . But in the case of vehicle emissions there is strong resistance from member countries with large automotive production such as Germany, as this will mean huge investments in green technologies for automakers, as the $30 \%$ reduction will not be based on current levels but on 2021 emissions when the most stringent rules come into effect than today. 
In this way, it is almost certain that other vehicles that do not have zero emission (electric and fuel cells) or low emission (plug-in hybrids) will be out of the market.

In the case of Brazil, common hybrid cars currently serving as an alternative to the emission of pollutant particles emit about $80 \mathrm{~g} / \mathrm{km}$ and are only considered "low emission" if they emit less than $50 \mathrm{~g} / \mathrm{km}$ of $\mathrm{CO}^{2}$ (OLIVEIRA, 2017).

For 2018, Brazil is planning to launch the Rota 2030 program, which defines the rules of the new automotive regime that will replace Inovar-Auto and aims to define a correlation between pollution and taxes, for example, the less polluting the car, the less will be its Industrialized Product Tax (IPI) rate. However, the main impasse is the need for government revenue, which is why, at the beginning of 2018, when the program comes into force, taxation will continue to be defined according to the cylinder capacity (power) of the engine, as it is today, which is a contradiction (OTTA, 2017).

It is imperative to reduce the levels of pollution caused by vehicles using fossil fuels, as well as to stimulate public transportation, and to make changes to the energy matrix (ethanol, biofuels, sugar cane diesel) instead of oil to move vehicles.

Another factor to be considered is that part of the Brazilian fleet is old, that is, composed of trucks and vehicles over the age of 20, using diesel or gasoline, and are responsible for emitting about 150 times more pollutants than the new ones models launched in the market. To give you an idea, these types of vehicles correspond to $35 \%$ of the national fleet and can emit up to $58 \mathrm{~g}$ of pollutants in the atmosphere, against $0.3 \mathrm{~g}$ of the new models sold in the market (CORREA, 2018).

The use of rail systems (underground high-capacity subway, monorail, VLT-Light Rail Vehicles) is essential for cities to have more urban mobility, improve soil occupation as well as improve environmental conditions.

The replacement of individual transport by public transport should be the priority of public managers who plan cities in order to reduce air pollution, noting that this causes people to die due to air pollution from the use of fossil fuel vehicles.

\subsection{The Effects of Air Pollution}

Air quality monitoring is important because it generates data on the current air quality condition, builds the data history and is the basis for guiding management and evaluating the effectiveness of an established program.

In Brazil, the response to the monitoring of air pollution was the creation of the National Air Quality Control Program (PRONAR) through CONAMA Resolution No. 05 of June 5, 1989 (VORMITTAG, 2014).

The first legal provision resulting from PRONAR was CONAMA Resolution No. 03 of June 28, 1990, which establishes national air quality standards, which is still in force today and is outdated, without updating the new scientific knowledge on the subject, determines the monitoring of air quality as attributed to each state of the federation (VORMITTAG et al, 2014).

In 2013, the Health and Sustainability Institute surveyed data in the National Air Quality Monitoring
Network and did not find compiled information that represented the national monitoring scenario, but identified that the only pollutants monitored are Total Suspended Particles (PTS) and are no longer considered to be relevant pollutants to be monitored by the American and European laws, since they have little importance in health effects due to the measurements of the particulate matter of smaller diameters (10 and $2.5 \mu \mathrm{m})$, now largely used (VORMITTAG et al, 2014).

Particulate matter (PM) is a set of pollutants made up of dust, smoke and all kinds of solid and liquid material that remain suspended in the atmosphere because of its small size, which is directly associated with its potential to cause health problems, (VORMITTAG et al, 2014). However, it is important to note that there is no evidence that this effect has been associated with an increased risk of pulmonary alveoli.

The main sources of particulate emissions to the atmosphere are the burning of fossil fuels in internal combustion engines of motor vehicles, thermoelectric, industrial processes, construction dust, resuspension of soil dust, biomass burning, forest fire, and aerosol (VORMITTAG et al, 2014).

The emission of particulate matter per day according to WHO should not exceed $25 \mu \mathrm{g} / \mathrm{m}^{3}$ (micrograms per cubic meter), and from $50 \mu \mathrm{g} / \mathrm{m}^{3}$ the level is considered to be an emergency and may cause health damage (WHO, 2014).

In Brazil, the tolerated level is $150 \mu \mathrm{g} / \mathrm{m}^{3}$, which corresponds to three times the WHO emergency level and in the state of São Paulo, since 2013, by state decree, reduced that level to $120 \mu \mathrm{g} / \mathrm{m}$ (VORMITTAG et al. al, 2014).

According to a study by the International Energy Agency (IEA), released on 27 June 2016, about 6.5 million people die every year worldwide due to air pollution, with the transport sector being among the main responsible (BAZANI, 2016).

According to the WHO, 22,000 people die annually in Brazil from air pollution, and by 2040 they will average 36,000 (WHO, 2014).

Table 2: Premature death cases attributable to outdoor air pollution by selectec region and scenario

\begin{tabular}{|c|c|c|c|c|c|c|c|c|}
\hline & & $\begin{array}{c}\text { European } \\
\text { Unilon }\end{array}$ & Mexico & China & Indha & Indonesia & Brall & $\begin{array}{l}\text { South } \\
\text { Africa }\end{array}$ \\
\hline \multirow[t]{3}{*}{2015} & Mean & 339600 & 12500 & 1049600 & 590400 & 71100 & 22000 & 14800 \\
\hline & Upper range & 458400 & 17000 & 1489200 & 880600 & 98900 & 30200 & 20300 \\
\hline & Lower range & 220700 & 8300 & 523500 & 359000 & 36800 & 14000 & 8200 \\
\hline \multirow[t]{3}{*}{2040 NPS } & Mean & 226300 & 15500 & 1495300 & 915600 & 117800 & 36100 & 16900 \\
\hline & Upper range & 305500 & 21900 & 2122700 & 1374900 & 163700 & 50200 & 23700 \\
\hline & Lower range & 147100 & 10300 & $m 2400$ & 548600 & 60000 & 23200 & 9000 \\
\hline \multirow[t]{3}{*}{2040 CAS } & Mean & 177200 & 5700 & 1085600 & 559100 & 19100 & 13300 & 4000 \\
\hline & Upper range & 239200 & 9800 & 1515100 & 760200 & 26600 & 19800 & 5600 \\
\hline & Lower range & 115100 & 3300 & 618100 & 362800 & 12400 & 8300 & 2600 \\
\hline
\end{tabular}

Note: NPS = New Policies Scenario; CAS = Clean Air Scenario, Source: IIASA.

According to Silver (2017), the scientific journal The Lancet ranked 148th in the ranking of countries with the 
highest proportion of pollution-related deaths, behind other South American nations such as Uruguay, Chile and Ecuador.

For general mortality, the total number of deaths is expected to range from 236,000 to 256,000 in 18 years. Total hospitalizations are close to one million, which means an expenditure of over US \$500 million at 2011 prices.

A study by André et al. (2012) indicates that the delay in the implementation of cleaner sulfur reduction policies leads to an increase of almost 14,000 deaths by 2040 and more than 18,000 hospitalizations in the public health network in six Brazilian metropolitan regions, estimated cost in the order of $\$ 11.5$ billion by 2040 calculated by the welfare measure.

It is important to note that death estimates may be underestimated, since IBGE mortality data (2013) were used to calculate the projections.

It is observed that the countries where the highest number of deaths occur are developing countries, where there are few or precarious policies to reduce emissions of polluting gases.

According to VORMITTAG et al, 2014, it was verified that:

- Each human being breathes on average $20 \mathrm{k}$ liters of air / day;

- Air pollution affects climate, human body and air quality for the future;

- $92 \%$ of the population live in areas that exceed recommended pollution levels;

- Pollution affects $80 \%$ of people living in cities;

- Accounts for 1 in 4 deaths caused by heart problems;

- $98 \%$ of cities with more than 100,000 inhabitants in developing countries do not follow WHO guidelines on air quality.

In view of this scenario, it is important to replace the energy matrix based on fossil fuels with other clean and renewable energy sources.

\section{FINAL CONSIDERATIONS}

To make transport systems truly sustainable, society needs to rethink the entire mobility system, looking for ways to reduce its dependence on vehicles, including changes such as car sharing, better public transport infrastructure and increased use of modal emission-free or low-emission transport.

The volume of emissions avoided with the use of biofuels in Brazil is a direct result of the public policies adopted, therefore, policies aimed at maintaining investments in the production of ethanol are important to maintain the conditions of supply of this biofuel at a competitive price compared to gasoline, which can be realized through tax differentiation.

A negative aspect is the high share of fossil fuels in the matrix of passenger and cargo transport, pressing $\mathrm{CO}^{2}$ emissions, so a transport policy that prioritizes the diversification of electric-powered modes would be fundamental for the reduction of fuel consumption fossils and emissions of polluting gases.

The commercial-scale sale of electric and hybrid vehicles in Brazil can contribute to the reduction of emissions of gaseous pollutants, as they reduce carbon emissions by $54 \%$ compared to gasoline, but for this to happen it will be necessary to create encouraging the dissemination of hybrid and electric vehicular technologies to lower the cost of purchasing these vehicles.

However, there is no indication in the Ten Year Energy Expansion Plan (PDE 2026) that this energetic transition will take place until 2026, against a growing list of countries that have decided to ban the sale of cars for internal combustion over the next 25 years (EPE, 2017).

Commitments made at the Conference of the Parties (COP) on greenhouse gas emissions have led participating countries to provide tax incentives to accelerate the transition, in addition to introducing a ban on the sale of domestic combustion cars in 2040.

However, in Brazil this does not occur, as there are no policies that encourage the production and sale of electric vehicles. In recent years, the country has implemented policies that stimulate the production, sale and consumption of fossil fuels (gasoline and diesel), as well as granting tax exemptions, such as the reduction of the Industrialized Products Tax (IPI) reduction of the Contribution of Intervention in the Economic Domain (CIDE) in the price of gasoline and diesel oil.

In Brazil, it is estimated that the cost of hospital deaths and hospitalizations resulting from air pollution is equivalent to approximately half a million dollars a year for approximately one million people hospitalized, and the estimated number of deaths the next 18 years varies between 236 thousand and 256 thousand people per year.

Particularly among the leading causes of death worldwide, pollution has played a major role, mainly pollution from the burning of fossil fuels, notably used by motor vehicles.

In view of the situation of health and environmental damage related to the degradation of air quality, as well as all the legislative limitations in the country, air pollution is an increasing threat to human health and urgent needs for action.

\section{REFERENCES}

[1] ANDRÉ, P. A.; VERAS, M. M.; MIRAGLIA, S. G. E. K.; SALDIVA, P. H. N. Lean diesel technology and human health: a case study in six Brazilian metropolitan regions. Clinics, vol.67, no.6. São Paulo, 2012. Disponível em: < http://dx.doi.org/10.6061/clinics/2012(06)15>. Acesso em 25 de abril de 2017.

[2] ANFAVEA. Carta da Anfavea - dezembro 2017. 2017. Available at: < http://www.anfavea.com.br/cartas/carta379.pdf >. Accessed on: 29/12/2017.

[3] AVANSINI, Carolina. Efeito estufa: Brasil terã que reduzir em $43 \%$ a emissão de gases. Folha de Londrina. Londrina: Grupo Folha, 17 Dez. 2016. Available at: $<$ http://www.folhadelondrina.com.br/reportagem/efeitoestufa-brasil-tera-que-reduzir-em-43-emissoes-de-gases965739.html>. Accessed on: 28/10/2017.

[4] BARBOSA, Vanessa. Os 10 países com o ar mais poluído do mundo. Revista Exame. São Paulo: Grupo Abril, 17 Set. 2016. Available at: <https://exame.abril.com.br/mundo/os-10-paises-com-o-armais-poluido-do-mundo/\#>. Accessed on: 29/10/2017.

[5] BAZANI, Adamo. Os efeitos da poluição do ar na saúde, em mortes prematuras e na economia. Diário do 
Transporte. 20 Jul. 2016. Available at: <https://diariodotransporte.com.br/2016/07/20/os-efeitosda-poluicao-do-ar/>. Accessed on: 30/10/2017.

[6] BRASIL. Ministério da Ciência, Tecnologia, Inovações e Comunicações - MCTIC. Estimativas anuais das emissões de gases de efeito estufa no Brasil. Brasília, 2013. Disponível em: 〈sirene.mcti.gov.br/publicacoesb〉. Acesso em: 5 outubro 2017.

[7] BRASIL. Conferência das Partes. 2017. Available at: <http://www.mma.gov.br/clima/convencao-das-nacoesunidas/conferencia-das-partes>. Accessed on: 02/11/2017.

[8] CORREA, Carine. Setor de transporte é o que causa mais impactos na qualidade do ar. Available at: < http://www.mma.gov.br/informma/item/6191-setor-detransporte-e-o-que-causa-mais-impactos-na-qualidade-doar>. Accessed on: 02/01/2018.

[9] Brasília, DF: CEPAL. Escritório no Brasil/IPEA, 2010.

[10] ERBER, Fabio Stefano. Inovação tecnológica na indústria brasileira no passado recente: uma resenha da literatura econômica. Brasília, DF: CEPAL. Escritório no Brasil/IPEA, 2010.

[11] FIANI, Ronaldo. Cooperação e conflito: instituições e desenvolvimento econômico. Rio de Janeiro: Elsevier, 2011.

[12] GERSSEN-GONDENLACH, Sarah H.; FAAIJ, André P. C. Performance of batteries for electric vehicles on short and longer term. Journal of Power Sources. v. 212, 15 Ago. 2012, p. 111-129.

[13] GOLDENSTEIN, Marcelo; AZEVEDO, Rodrigo Luiz Sias de. Combustíveis alternativos e inovações no setor automotivo: será o fim da "era do petróleo"? BNDES Setorial, Rio de Janeiro, n. 23, p. 235-267, mar. 2006.

[14] IBGE - Instituto Brasileiro de Geografia e Estatística. Tábua completa de mortalidade para o Brasil - 2013 Disponível em: <ftp://ftp.ibge.gov.br/Tabuas_Completas_de_Mortalidade/ Tabuas_Completas_de_Mortalidade_2013/notastecnicas.p df>. Acesso em: 06 jun. 2017.

[15] IPEA - Instituto de Pesquisa Econômica Aplicada. Impactos Ambientais e Econômicos dos Veículos Elétricos e Híbridos Plug-In: uma revisão da literatura. Rio de Janeiro : Ipea, Ago, 2015.

[16] MARTINS, Claudia do Nascimento. Condicionantes da difusão do carro elétrico no Brasil: análise dos fatores institucionais, econômicos e técnicos. 2015. 222 f. Tese (Doutorado em Políticas Públicas, Estratégias e Desenvolvimento) - Instituto de Economia, Universidade Federal do Rio de Janeiro, Rio de Janeiro. 2015.

[17] MARTINS, Rafael Acosta. Os efeitos da poluição do ar na saúde, em mortes prematuras e na economi Brasil tem aumento de $34 \%$ na emissão de $\mathrm{CO}^{2}$ no século 21 . Jornalismo de Dados. 10 Jul. 2017. Available at: < https://medium.com/jornalismo-de-dados/brasil-temaumento-de-34-na-emiss\%C3\%A3o-de-co2-nos\%C3\%A9culo-21-21a75fcfd1a2>. Accessed on: 25/10/2017.

[18] MINISTÉRIO DO MEIO AMBIENTE. Proconve: programa de controle de poluição do ar por veículos automotores. Disponível em: http://www.mma.gov.br/estruturas/163/_arquivos/proconv e_163.pdf $>$. Acesso em: 12 de novembro de 2017.

[19] NORTH, Douglas C.; DAVIS, L. E. Institutional Change and American Economic Growth, Cambridge University Press, Cambridge, 1971.

[20] EPE - Empresa de Pesquisa Energética. Plano Decenal de Expansão de Energia 2026 (PDE 2026). Julho, 2017. Disponível em: 〈http://www.epe.gov.br/pde/Paginas/default.aspx >. Acesso em: 12 de setembro de 2017.
[21] OLIVEIRA, Ricardo de. União Europeia quer estabelecer meta de 66,5 g/km nas emissões de $\mathrm{CO}^{2}$ em 2030. Notícias Automotivas. Pouso Alegre: Minas Gerais. Disponível em: <https://www.noticiasautomotivas.com.br/uniaoeuropeia-quer-estabelecer-meta-de-665-gkm-nas-emissoesde-co2-em-2030/>. Acesso em: 30 de setembro de 2017.

[22] OTTA, Lu Aiko. Novo regime automotivo vai ficar para o ano que vem. O Estado de S.Paulo. 14 Out. 2017. São Paulo: Grupo Estado. Disponível em: <http://economia.estadao.com.br/noticias/geral,novoregime-automotivo-vai-ficar-para-o-ano-quevem,70002044413>. Acesso em: 22 de outubro de 2017.

[23] PAMPLONA, Nicola. Governo analisa usar térmicas mais caras para enfrentar crise energética. Folha de S.Paulo. 30 Out. 2017. São Paulo: Grupo Folha. Disponível em: $<$ http://economia.estadao.com.br/noticias/geral,novoregime-automotivo-vai-ficar-para-o-ano-quevem,70002044413>. Acesso em: 31 de outubro de 2017.

[24] SILVER, Katie. Poluição mata mais de 100 mil pessoas por ano no Brasil. BBC Brasil. 20 Out. 2017. São Paulo: Grupo BBC. Disponível em: <http://www.bbc.com/portuguese/geral-41692503>. Acesso em: 29 de outubro de 2017.

[25] TIGRE, Paulo Bastos. Gestão da Inovação: a economia da tecnologia no Brasil. Rio de Janeiro: Campus, 2006.

[26] VORMITTAG, Evangelina M. P. A. A. et al. Monitoramento da Qualidade do Ar no Brasil Junho/2014. Disponível em: < http://www.saudeesustentabilidade.org.br/publicacao/pesq uisa-monitoramento-da-qualidade-do-ar-no-brasil/> . Acesso em: 30 de outubro de 2017.

[27] WHO - World Health Organization. 7 million premature deaths annually linked to a ir pollution. Geneva: WHO, 2014. 